\title{
BENEFITS AND INCONVENIENCES \\ OF THE PRACTICAL IMPLEMENTATION OF ENVIRONMENTAL LIFE CYCLE COSTING
}

\section{Michał Biernacki}

Wrocław University of Economics, Wrocław, Poland

e-mail: michal.biernacki@ue.wroc.pl

ORCID: 0000-0002-7269-8212

\section{(C) 2018 Michał Biernacki}

This is an open access article distributed under the Creative Commons Attribution-NonCommercial-NoDerivs license (http://creativecommons.org/licenses/by-nc-nd/3.0/)

DOI: 10.15611/fins.2018.3.01

JEL Classification: Q56

\begin{abstract}
Environmental Life Cycle Costing (ELCC) combines life cycle analysis and cost systems applied by managers in order to assess the limitations of environmental production systems. It enables the evaluation of progress in implementing sustainable development by determining the social costs of resource consumption and environmental degradation. This study presents the results of empirical research covering production enterprises with foreign equity participation operating in Poland which have the basic ELCC model in place. The research is aimed to identify the benefits and inconveniences arising from the practical application of the model as a significant factor determining its functioning in entities. The research methodology was supplemented by numerous literature items, analysis of survey questionnaires, as well as deduction and induction methods.
\end{abstract}

Keywords: ELCC, costing, green accounting.

\section{Introduction}

According to IFAC assumptions, environmental management accounting (EMA) is managing the environment through the development and implementation of suitable accounting systems and practices related to environmental protection. It includes, among others, reporting and audit, environment-related cost analysis as well as life cycle costing, assessment of benefits, and strategic planning for environmental management [International Guidance... 2005, p. 21]. The United Nations for EMA determined the physical and financial nature of environmental management accounting. It is defined as the identification, collection, analysis and use of two types of information for making management decisions with environmental aspects taken into consideration. One is physical information about the consumption, flow and final disposal of energy, water and materials as well as waste, while the other is 
monetary information about the costs, revenues and savings related to environmental protection [United Nations Division... 2001]. A full EMA implication in an enterprise also consists in also an assessment of the environmental impact and the costs involved in specific types of materials and products. The combination of life cycle assessment (LCA) and life cycle costing (LCC) enables the implementation of the so-called environmental life cycle costing as part of EMA. The simultaneous aggregation of the information coming from inside the enterprise and from the contracting parties translates into the implementation of the environmental aspect to both accounting and management.

\section{Assumptions of Environmental Life Cycle Costing}

According to its original assumptions, environmental life cycle costing is the assessment of the economic dimension of production as regards environmental impact and the satisfaction of the definition of sustainable development. It is a method of estimating the environmental impact of production which can be expressed in both quantitative and qualitative terms and hence be fully used for measuring the progress of the ecological activities of an enterprise.

The purely environmental dimension of goods production is determined by the application of the Life Cycle Analysis method. However, it ignores economic and social aspects [Hendrikson et al. 2006, pp. 10-12]. Hence their simultaneous combination as a comprehensive solution is an assumption of environmental life cycle costing and therefore, to put it simply, it is a combination of Life Cycle Costing and the LCA method.

The main objectives of this costing model include:

- comparison of life cycle costs of alternative or similar projects;

- detection of direct and indirect carriers of traditional and environment-related costs;

- determination of external and internal environment-related costs occurring during production;

- registration and analysis of improvements with regard to a given product;

- qualitative and quantitative estimation of the planned product changes, including changes in the life cycle process;

- identification of the "win-win" situation and the "golden mean" between the environmental - economic - social aspects of the product life cycle;

- definition, determination, analysis of the environmental impact of production and the offered product in monetary values [Hunkeler et al. 2008, p. 36].

Collecting the data required for carrying out the calculation as part of Environmental Life Cycle Costing (ELCC) relies, by analogy to LCA, on unit data, which are assigned directly to a unit product and/or process. A unit process is a single process or a subsystem composed of several processes, for which separable data are gathered. It needs to be emphasised that the aggregation level for individual products 
and processes can considerably differ in practice since the availability of data, cost recording methods, qualitative data, technical and technological data, as well as the goals and scope of a given assessment, is varied and unsystematised [Kumaran et al., pp. 260-276].

As part of the ELCC calculation, an enterprise's indirect costs can be determined and assigned to individual products and processes based on general, traditional allocation keys or with the use of, for example, activity-based costing.

At the same time, it needs to be remembered that discounting should be included in the calculation for the processes occurring in the medium and long-term (e.g. the recycling of washing machines after a period of use).

\section{Benefits and inconveniences of ELCC implementation in light of the author's research}

The study was conducted between March and September 2017, based on electronic surveys distributed via e-mail. The first stage of the research involved 81 companies operating in Poland. This represents the definitive size of the respondent sample, after discounting the body of incomplete or flawed responses. The surveys were distributed among: (1) representatives of 350 companies (accountants and chief financial officers) recruited at accountancy certification courses organised by the Lower Silesian branch of the Accountants Association in Poland, (2) attendees of postgraduate courses of the studies 'Personnel and Payroll' and 'Expert of accounting services' organized by the Wroclaw University of Economics, and (3) companies listed in the databases of two accounting offices (both wishing to remain anonymous). All the surveys were sent via e-mail to registered addresses and yielded 99 responses, of which 81 were qualified for analytical purposes (the remaining were either incomplete or with errors). Thus the response rate was 23\% (in terms of responses qualified as valid). The study assumed that the selection of respondents would be based on stratified sampling. However, considering the limitations in the access to relevant data and the voluntary nature of the survey, the results may be distorted. From the viewpoint of the subject at hand, 24 companies in the production sector were qualified for the second stage of the study. All of them reported the use of at least the ELCC standard of cost accounting. The respondents had capital ties with foreign companies, in particular in Germany and the US. The second stage yielded a total of 24 responses (a response rate of 100\%), regarding the benefits and inconveniences resulting from the implementation of the ELCC model. In addition, semi-structured interviews were conducted to confirm the responses obtained in specific segments of the survey. The results of the study are presented in Figures 1 and 2.

The improvement in determining various indirect or partly hidden environmentrelated costs, the contingent costs, occurring in the case of specific environmental decisions or product/process character, as well as less unambiguous costs, which can 


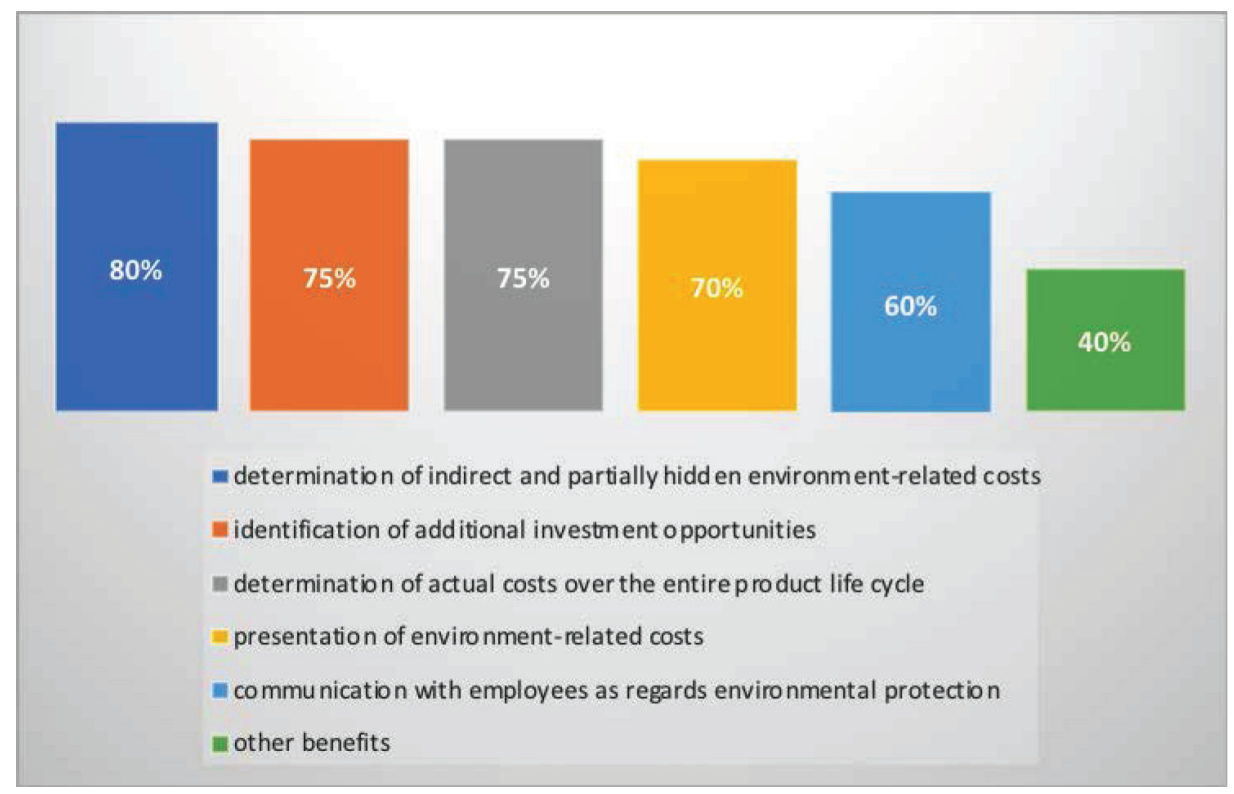

Fig. 1. Benefits of ELCC implementation

Source: own research.

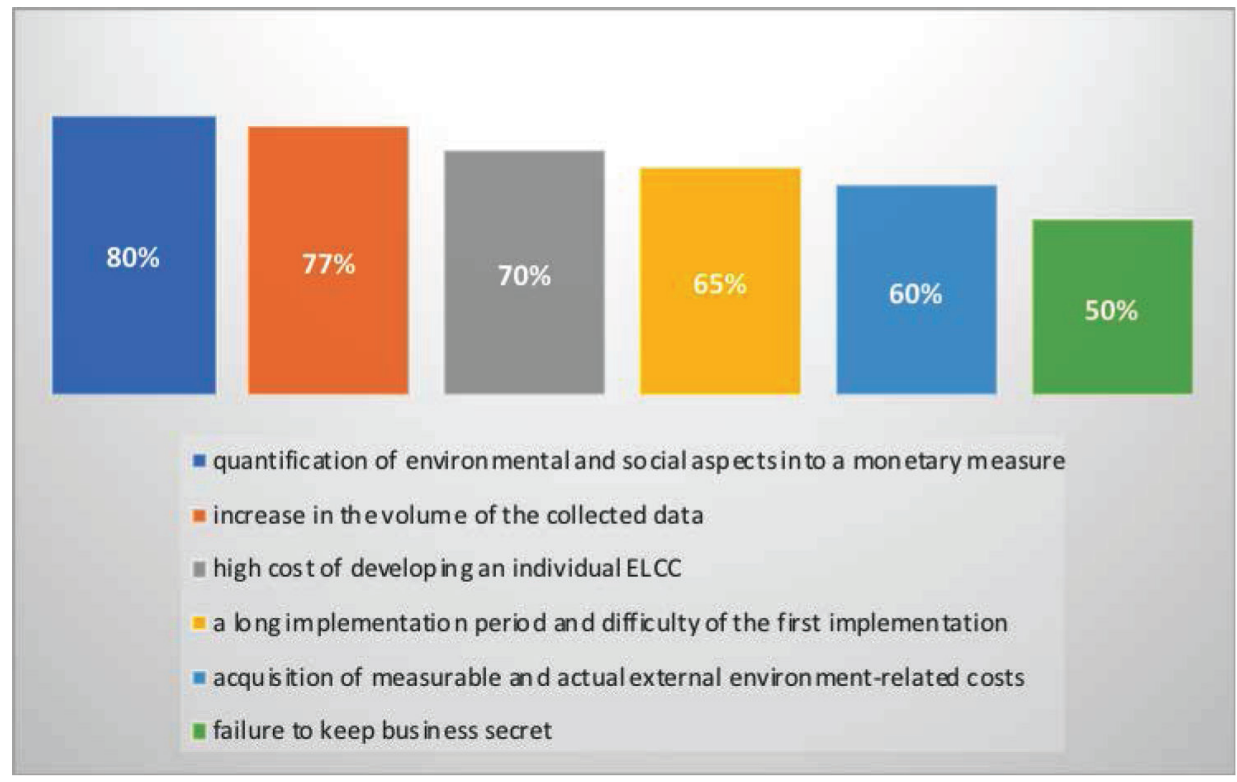

Fig. 2. Inconveniences of ELCC implementation

Source: own research. 
be classified among environmental ones, the implementation benefits were signalled in first place ( $80 \%$ of indications). This is related to the ELCC's concentration mainly on the cost structure, cost assignment to individual financial operations and transactions (e.g. ordering materials). A better understanding and management of environment-related costs and other costs in the whole life cycle, also has a direct influence on determining the costs to be incurred by the customer.

All transactions taking place on the market imply a range of competitive activities on the one hand as well as supplementary ones, which improve an enterprise's operational activity (e.g. updating the offer) on the other hand. Such activities can support and expand the entity's infrastructure required for the effective use of goods or services, $75 \%$ of the respondents indicated that environmental LCC was an effective tool for identifying additional business/investment opportunities by expanding the scope of the environmental analysis in the short and long run.

Also $75 \%$ of the respondents declared that determining the actual costs occurring in the product life cycle was one of the benefits of implementing environmental life cycle costing. Actual costs are understood to include external and internal environment-related costs and allow for the internalisation of certain unrecorded effects of processes and production which could occur for society in the long run. Such costs are an element supplementing and complementing the social perspective. With this approach, environmental life cycle costing becomes a valuable instrument used for assessing future projects, and developing innovative solutions - the basis for the LCM system.

By presenting environmental and financial information, an enterprise can inform its contracting parties, customers, society, and governmental institutions about other events and circumstances it considers relevant in the context of environmental protection, and the implementation of environmentally friendly actions. The external presentation of environment-related costs through ELCC implementation was pointed out by $70 \%$ of the surveyed enterprises. The fact that businesses increasingly pay attention to the social and environmental aspects of production more frequently contributes to the positive external image. The calculation performed as part of environmental life cycle costing serves the purpose of presenting non-financial information about environmental protection activity for the local community along with the information about the effect of such activities on the enterprise's financial results and their components. The external reporting of environment-related costs in the whole product life cycle automatically creates a positive investment climate around the enterprise, in particular for long-term investors. The stakeholders who have exhaustive and reliable data on the environmental strategy actions that are in line with sustainable development, "clean" production and "green" products are more stable, do not make rapid sales movements on the capital market. On the contrary, they begin to buy more securities over a short period after investment finalisation.

Sixty percent of the surveyed enterprises declared that, as a result of ELCC implementation, they gained transparent communication with employees, customers 
and contracting parties as regards providing information about production processes and their environmental impact. Informing about socially responsible actions in the area of environmental protection which occur during production, contributes to maintaining or reinforcing the desired relationships by persons engaged in environmental problems in such economic entities.

Other benefits of ELCC implementation indicated by the surveyed entities (40\% of the businesses mentioned these benefits) include:

- avoidable unfavourable responses and actions on the part of governmental institutions in the form of penalties, fines, concession restrictions, temporary or permanent withholding of sales on a given market;

- quicker adaptation to amendments to the law, if any, and the possibility to apply for 'vacatio legis' by backing themselves up with the pursued 'friendly' and 'transparent' environmental policy and production;

- development of an individual model - the management tool for assessing the enterprise's strategy in the context of environmental, social and economic effects of production;

- better understanding of the essence and significance of the environmentally friendly activity by employees;

- improved quality of non-financial, i.e. social and environmental, information;

- integration of external and internal reporting in environmental, social and onomic areas, which are used in the operational and strategic management process;

- positive impact on the effectiveness of the social and environmental decisions made by enterprises;

- full analysis of the external environment-related costs and their significance in environmental protection.

However, the ELCC model is not free from the limitations arising from the greater scope of implementation works as well as the disclosures and the character of social and environmental information.

Environmental and social information is largely dependent on the nature of the given enterprise, which translates into the extremely problematic quantification of the information into a monetary measure. This is an inconvenience indicated by $80 \%$ of the examined entities. According to the respondents, this could influence the reliability of the information related to estimates and forecasts.

Due to the nature of ELCC, which combines many aspects and consequently, data, there is a risk of an increase in their volume, that is "overloading." This involves exhaustive analytical work, possible mistakes in calculations and analyses, and finally potentially misleading external and internal recipients. This inconvenience was marked by $77 \%$ of the examined entities. The information about the environmental and social impact of production and products are expected by stakeholders. Hence, efforts and attempts should be made to standardise the collected information and the prepared reports in order to increase the comparability and effectiveness of their use. 
Another problem noticed by entrepreneurs when implementing the environmental life cycle costing model is the relatively high cost of developing an individual ELCC (70\% of positive answers) and the long time of its implementation, as well as the difficulty in applying it for the first time (65\% of positive answers).

Undoubtedly the problem with obtaining measurable and real external environment-related costs (as indicated by 60\% of the respondents), is also a limitation to the ELCC model. This is related to the time-consuming nature of their obtainment, compilation and presentation. As regards environment-related costs, a considerable portion of them is obtained from internal systems and their appropriate structuring does not require a high workload or costs. Yet, the case is different for external environment-related and social costs. Introducing new and more extensive information about them will generate higher costs in the initial periods but it will translate into a change or improvement of the already employed information flow channels.

Environmental life cycle costing, in an attempt to satisfy stakeholders' expectations regarding the disclosed environmental information, can fail to keep the business confidentiality regarding its calculations and presentations. This problem was pointed out by $50 \%$ of the surveyed businesses. Presenting information about social and environment-related costs, which can be classified as information of strategic significance, externally could lead to lower competitiveness and, in extreme situations, to the court (e.g. for polluting the nearest environment and deteriorating the local community's health) and thus bring benefits to competitors.

\section{Conclusion}

As follows from the conducted questionnaire survey, it is the possibility to assess and analyse environment-related costs, full product life cycle costs and social costs that is of a fundamental importance to the entrepreneurs who have implemented the ELCC model. They are burdened with a big dose of subjectivism and uncertainty about the future, which might result in the risk of an error in interpretation. It needs to be stressed that the information obtained from the implementation of the environmental life cycle costing model is closely related to the character of the enterprise and the sector in which it operates, as well as to the applied technologies and technical considerations. What is also worth emphasising is the enterprises' approach to ELCC implementation. The barrier which occurs when introducing this model is the repeated and common adoption of a short-term investment and management horizon. However, changes in the behaviour of purchasers and other stakeholders can contribute to a change in the short-term behaviour and the abandonment of a reliance on short-term financial data.

At the same time, with its comparative and systemic nature oriented towards making decisions in the context of sustainable development, ELCC is not a substitute for the traditional cost allocation methods or cost management methods. It is a specific, 
defined and standardised instrument for estimating significant differences in making decisions between alternative products based on real cash flows. At the same time it can serve the purpose of determining the product improvement and upgrading the potential over one life cycle, focusing on both the impact of the production process and environmental impact. It is a comprehensive method aimed at a consistent attitude to approaching the offered product from environmental, social and financial angles.

The ELCC model has numerous important advantages but also certain flaws and limitations. Its application meets the assumptions of sustainable development and corporate social responsibility policies. The identification of social costs and environment-related costs by enterprises facilitates the improved quality and reliability of an entity among all its stakeholders. This complements and supplements its obligatory disclosures. As part of the conducted research, none of the enterprises regretted its decision to implement the model. The identified and indicated benefits outweighed the problems, inconveniences and difficulties.

\section{Bibliography}

Hendrikson C.T., Lave L.B, Matthews H.S., 2006, Environmental Life Cycle Assessment of Goods and Services. An Input and Output Approach, RFF Washington, pp. 10-12

Hunkeler D., Lichtenvort K., Rebitzer G., 2008, Environmental Life Cycle Costing, CRC Press SETAC. International Guidance Document Environmental Management Accounting, 2005, IFAC, NY, pp. 20-22. Kumaran D.S., Ong S.K., Tan R.B.H., Nee A.Y.C., 2001, Environmental life cycle cost analysis of products, Environmental Management and Health, vol. 12, Issue 3.

United Nations Division for Sustainable Development, Environmental Management Accounting, Procedures and Principles, 2001.

\section{KORZYŚCI I OGRANICZENIA ZWIĄZANE Z WDROŻENIEM RACHUNKU ELCC W PRZEDSIĘBIORSTWACH}

Streszczenie: Rachunek ELCC łączy badania analizy cyklu życia z systemami kosztów stosowanymi przez menedżerów w celu oceny ograniczeń systemów środowiskowych, produkcyjnych. Umożliwia dokonanie oceny postępów we wdrożeniu zrównoważonego rozwoju przez określenie społecznych kosztów zużycia zasobów i degradacji środowiska. W pracy przedstawiono wyniki badań empirycznych z badań firm produkcyjnych działających na terenie Polski z kapitałem zagranicznym, które mają wdrożony podstawowy model ELCC. Badanie miało na celu określenie korzyści i niedogodności związanych z wdrożeniem tego modelu w praktyce jako ważnego czynnika determinującego jego funkcjonowanie w jednostkach. Metodologia badań została uzupełniona o liczne źródła literaturowe, analizę ankiet oraz metody dedukcji oraz indukcji.

Slowa kluczowe: ELCC, costing, green accounting. 